\title{
Pinus sylvestris L. subsp. nevadensis (Christ) Heywood in southern Spain: An endangered endemic Mediterranean forest
}

\author{
José Antonio Olmedo-Cobo ${ }^{A *}$, José Gómez-Zotano ${ }^{A}$, José Luis Serrano-Montes ${ }^{A}$ \\ Received: February 21, 2017 | Revised: June 18, 2017 | Accepted: June 23, 2017 \\ DOI: $10.5937 /$ GeoPan17031510
}

\begin{abstract}
Pinus sylvestris subsp. nevadensis is the most endangered pine in Spain. This taxon takes refuge in only two massifs of the Betic Cordillera -Sierra Nevada and Sierra de Baza-, where its forests represent the southernmost limit of the species global distribution, surviving under conditions of geographic, demographic and ecological marginality in the upper treeline boundary that makes them very vulnerable to any environmental change or external aggression. This research establishes for the first time, and for the entire Betic Cordillera, the locations and ecological patterns of these pine forests, their plant dynamic and floristic composition, and provides an updated map of the current and potential distribution area of this subspecies. The methodological process for this research has consisted of an integrated phytosociological and biogeographical analysis of vegetation and the resulting landscape, through fieldwork covering in as much detail as possible the distribution area of $P$. sylvestris in the Betic Cordille$\mathrm{ra}$, and a review of the bibliographic background. Taking into account the results, P. sylvestris subsp. nevadensis forests survive at present under hostile Mediterranean conditions due to the special physical characteristics of the microenvironments in which they have taken refuge, mainly the cool, relatively moist climate of their ecological niches and the relatively impermeable soils that forests occupy. However, there are significant ecological obstacles for the future preservation of this pine in southern Spain, and therefore it is necessary for the creation of programmes to protect these threatened endemic and post-glacial relict forests through continued monitoring of their evolution and further research studying the processes that make this ecosystem as a whole so unique and valuable.
\end{abstract}

Keywords: Scot pine, Sierra Nevada, Sierra de Baza, ecological patterns, plant dynamic, floristic composition, current distribution map.

\section{Introduction}

Scot pine -Pinus sylvestris L.- is the most widely distributed taxon of the Pinus genus around the world, occupying an outstanding place in the European vegetation throughout the Quaternary period (the last 1,6 Ma) (Kelly, Connolly, 200o; MacAllister, 2016). The species has an extensive geographical distribution in much of Europe and Asia at present -it is the most common tree in these territories- having been culti- vated for a long time (Koski, 200o), which colonizes numerous mountain habitats covering a broad latitudinal gradient of ecological conditions, therefore having an important morphological diversity (Costa, et al., 2005; MacAllister, 2016). The native forests grow in wet-cold, very cold, and extremely cold continental bioclimates, preferably in oroboreal phytoclimates (Rosúa, et al., 2001; Costa, et al., 2005) of the EasternSiberian, Euro-Siberian, and Mediterranean biogeo-

\footnotetext{
A Department of Regional Geographic Analysis and Physical Geography, University of Granada. Facultad de Filosofía y Letras, Campus de Cartuja s/n. 18071, Granada, Spain; jaolmedo@ugr.es, jgzotano@ugr.es,joselsm@ugr.es;

* Corresponding author: José Antonio Olmedo-Cobo, e-mail: jaolmedo@ugr.es
} 
graphic regions of the Holarctic Kingdom. This is the widest natural chorological area of any pine species on the Earth (Kelly, Connolly, 2000; Mason, Alía, 2000).

South of its ecological area, $P$. sylvestris is an increasingly rare taxon, particularly in the Mediterranean Basin, where the species has a terminal distribution conditioned by the dry boundary of the sub-Mediterranean climate, remaining confined within this climate or in other axeric temperate or sub-axeric cold domains (Ruiz de la Torre, 2006). The availability of edaphic and environment humidity during the summer under Mediterranean conditions provides its main limiting factor (Xenakis, et al., 2012). For example, it has been found that the specific leaf area is lowest for the Spanish provenances of P. sylvestris in comparison with other Eurosiberian provenances, which is related to the droughts and dry periods (MacAllister, 2016). In particular, in the Iberian Peninsula these forests took refuge in certain high mountain regions after their regression since the end of the Last Glacial Maximum (Ruiz-Labourdette, et al., 2012), where they currently form the western and southernmost limits of the natural distribution range of $P$. sylvestris (Mason, Alía, 2000; Andreu, et al., 2007; Martínez-Vilalta, et al., 2008). These circumstances have favoured its disjunct distribution in several Spanish mountain ranges and the development of five subspecies derived from two different Iberian haplotypes that existed during the Würm period (Cheddadi, et al., 2006): catalaunica Gaussen and olivicola Vayr (NE Iberian mountains), iberica Svoboda (Central and Iberian Cordilleras), pyrenaica Svoboda (central and western Pyrenees), and nevadensis (Christ) Heywood (Betic Cordillera, southern Iberian Peninsula).

Of all these Iberian subspecies, $P$. sylvestris subsp. nevadensis is the most endangered occurring only in two geographically isolated massifs of Betic Cordillera (southern Iberian Peninsula): Sierra Nevada (National Park and Biosphere Reserve) and Sierra de Baza (Natural Park). In these massifs, the subspecies is found between 1,600 and 2,200 meters above sea level, occupying an ecological boundary of an upper treeline that makes it very vulnerable to any environmental change or external aggression. The Mediterranean climate (especially the resultant stress due to summer dryness), the small size of forests, and the lack of regeneration due to overgrazing are significant ecological obstacles to its preservation (Mason, Alía, 200o). Therefore, the subsp. nevadensis forests are considered endangered relict formations of great interest (Ruiz de la Torre, 2006) due to their paleoendemic character (based on palinological studies), high ecological value, and extreme fragility (Olmedo-Cobo, 2011).

This research presents for the first time a geoecological analysis of $P$. sylvestris subsp. nevadensis for the entire Betic Cordillera. Together with a review of earlier primary studies of this taxon (Valle, Gómez, 1988; Pérez-Raya, et al, 1990; Blanca, Morales, 1991; Molero, et al., 1992; Castro, 1999; Zamora, et al., 2001; Castro, et al., 2004, 2005; Costa, et al., 2005; Ruiz de la Torre, 2006; Olmedo-Cobo, 2011; Olmedo-Cobo, et al., 2014), fieldwork has been the main tool of analysis. The results obtained determine the current circumstances in which the species develops in such a hostile Mediterranean environment as the Betic Cordillera, and provide an updated map of the area occupied by these forests at present, corroborating and, where appropriate, reviewing the existing information. The data collected provides a valuable and integral tool that can be used for forestry management and the future preservation of this species, particularly in the face of the threats posed by climate change.

\section{Methods and data}

\section{Biogeography and bioclimatic context of study area}

The massifs of Sierra Nevada $\left(37^{\circ} 03^{\prime} 12^{\prime \prime} \mathrm{N}, 3^{\circ} 18^{\prime} 41^{\prime \prime} \mathrm{W}\right.$, Mulhacén peak-3,481 meters above sea level) and Sierra de Baza $\left(37^{\circ} 22^{\prime} 0^{\prime \prime} \mathrm{N}, 2^{\circ} 50^{\prime} 31^{\prime \prime} \mathrm{W}\right.$, Santa Bárbara peak2,269 $\mathrm{m}$ asl) are located in the central Betic Cordillera (southern Iberian Peninsula, Spain) (Figure 1), with a respectively territorial extension of $2,000 \mathrm{~km}^{2}$ and $600 \mathrm{~km}^{2}$.

These Holarctic territories belong to the Betic biogeographic province of the Mediterranean region (western Mediterranean subregion), and according to the latest biogeographical zoning of the Betic province, carried out by Rivas-Martínez (2011), the P. sylvestris subsp. nevadensis forests are located in the Trevenquino district of the Granadino-Almijarense sector in Sierra Nevada, and in the SerranoBastetano district of the Accitano-Bastetano sector in Sierra de Baza. Based on the premises established by Allué (1990), Rivas-Martínez and Loidi (1999), RivasMartínez et al. (2004) and Rivas-Martínez (2008) for the Mediterranean region, the P. sylvestris forests occur inside the subhumid-humid Supra-Oromediterranean bioclimate in Sierra Nevada, where the annual average rainfall is estimated to be $800-1,000 \mathrm{~mm}$ and the annual mean temperature ranges between $6^{\circ} \mathrm{C}$ at $2,000 \mathrm{~m}$ asl and $8^{\circ} \mathrm{C}$ at 1,600 $\mathrm{m}$ asl. Comparatively, the bioclimatic optimum of the nevadensis subspecies in Sierra de Baza corresponds to the subhumid Oromediterranean zone, with an annual average rainfall of approximately 700-800 mm and an annual mean temperature of $5-7^{\circ} \mathrm{C}$ above $1,800 \mathrm{~m}$ asl according to Olmedo-Cobo (2011). 


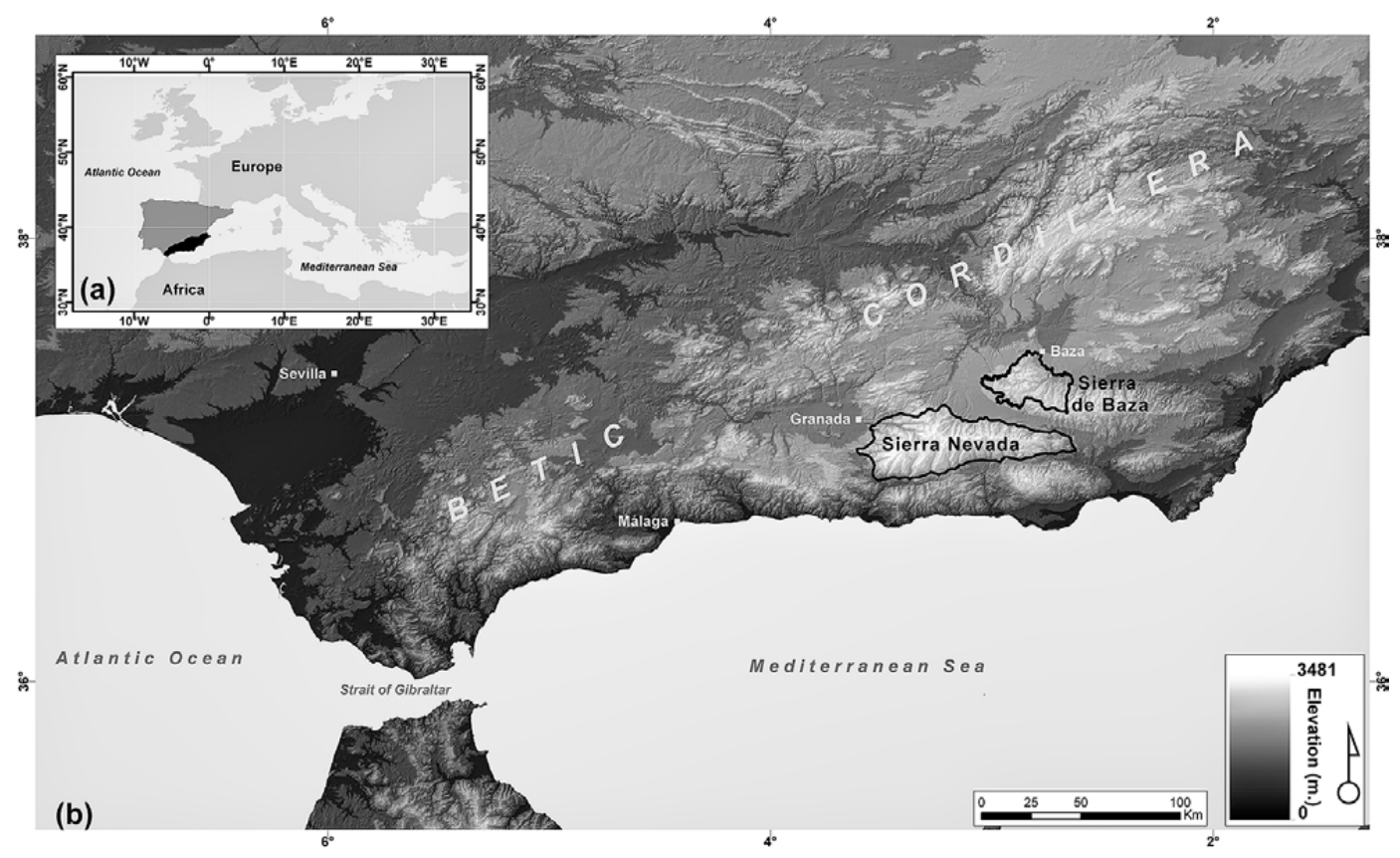

Figure 1. (a) Location of the Betic Cordillera (in black) in the Iberian Peninsula (in dark grey) and in the western Mediterranean Basin. (b) Sierra Nevada and Sierra de Baza occupy a central position in the mountain range, near the Mediterranean Sea

\section{Methodology}

The methodological process has been based on an integrated phytosociological and biogeographical analysis of vegetation and of the resulting landscape, which involves the study of the habitats, the vegetation series and geoseries, and the communities and floristic associations that comprise the dynamic and the plant succession of subsp. nevadensis forests. Through an approach based on extensive fieldwork the study area has been covered in as much detail as possible. This systematic review has established: (1) the ecological patterns of P. sylvestris subsp. nevadensis distribution in Sierra Nevada and Sierra de Baza massifs, (2) the plant dynamics and floristic composition of the different phytocoenosis recognized, and (3) the potential and current area -mapping- of P. sylvestris subsp. nevadensis forests.

The main references used for the designation, authorship, and verification of vegetation series and flora have been the works of Valle and Gómez (1988), Blanca and Morales (1991), Molero et al. (1992), Valle (2003), Castro et al. (2004; 2005), Castroviejo (2010) and Blanca et al. (2011). The study of the floristic composition of forests has been based on the Sigmatist Methodology of the Zurich-Montpellier school and the Braun-Blanquet abundance-cover index ${ }^{1}$ (see Braun-Blanquet,

1 Abundance-cover index: 5, any number of individuals, coverage $>75 \%$ of the study area; 4 , any number of individuals, coverage $50-75 \% ; 3$, any number of individuals, coverage $25-50 \%$; 2 , any number of individuals, coverage $5-25 \%$; 1 , numerous individuals, coverage $<5 \%$, or scattered individuals, coverage $>5 \%$; , few individuals, little coverage; $\mathrm{R}$, isolated individuals, little coverage.
1979). GIS (ArcGis 10.1) has been used for mapping, on the basis of data collected through fieldwork and the examination of aerial photographs from 2011, but also from 1977 and 1956 for the differentiation between native forests and reforestation masses. The lithological and edaphic references utilised to check the collected data have been obtained from Vera (2004), and the soils maps of the Lucdeme Project (scale 1:100.00o) (Spanish Ministry of Agriculture, Fisheries and Food, 1988-1990), respectively.

\section{Results}

\section{Locations and distribution patterns}

P. sylvestris subsp. nevadensis in Sierra Nevada is located in the Monachil River basin near the Trevenque and Tesoro peaks between 1,600 and 2,000 $\mathrm{m}$ asl (west of the massif, only $20 \mathrm{~km}$ of Granada city). The main forest cores occur in the N-NE slopes of Pico del Tesoro, in the confluence between the headwaters of theBenalcázar river and the Matas Verdes Hill (figure 2 left), and in the Huenes river near to Trevenquillo peak (E-NE slope of Trevenque peak). In Sierra de Baza (figure 2 right), the forests grow on several of the central and western slopes, between 1,800 and 2,250 m asl, mainly around the famous enclave of the natural park, Prados del Rey. Specifically, the most developed pinewoods appear on the $\mathrm{W}, \mathrm{NW}, \mathrm{N}$, and $\mathrm{NE}$ slopes of Santa Barbara peak, on the N and NE slopes of the Pozo de la Nieve peak, on the N and NW slopes of the 

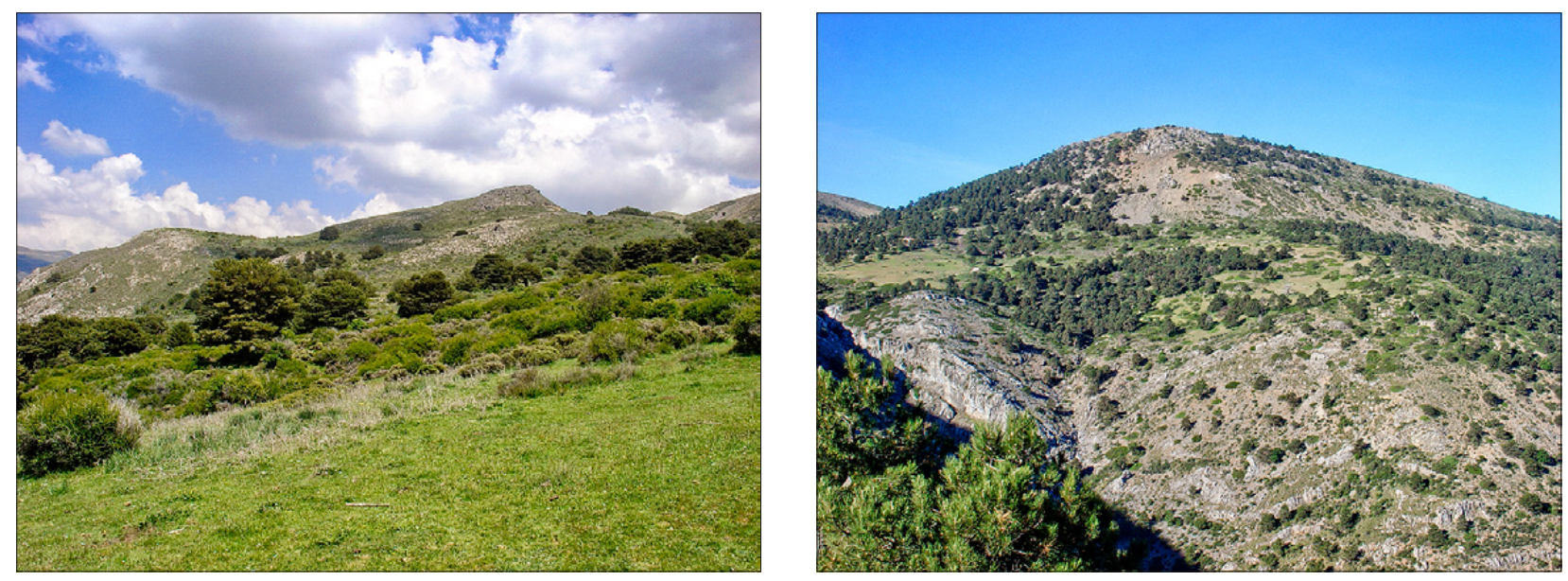

Figure 2. Scattered forest of $P$. sylvestris subsp. nevadensis in (Sierra Nevada) (left) and ecological environment of the subspecies in Sierra de Baza (right)

Source: Olmedo-Cobo

Cerro del Calar and Cerro del Sabinar peaks, and locally on the NW, N, and NE slopes of the San Sebastian and Rapa peaks; also, there are a few isolated individuals on other south orientations, as on the Peñón de la Cogollada peak, on the Relumbre Ravine, and on the La Boleta and Los Tejoletos hills.

At these locations, $P$. sylvestris occupies not overly steep slopes, oriented to north, northwest and northeast, emplacements that have an optimal exposure to the moist westerly air masses -associated with the polar jet stream- and a temperate (not warm) thermal regime in summer due to the elevation. The forests are also relatively protected from the scouring action of winds, which become an absolute limiting factor for woodlands on the summits of both massifs. Locally, the pines grow on steep periglacial screes, where water reaches the more superficial rocky stratums, being usable as reservoir by the trees during the summer or during drought periods. These are conditions that favour a moist, shady microclimatic environment with lower evaporation and evapotranspiration values and less sunshine during the hot and dry season with regard to the lower areas of both massifs.

Following the topographic and microclimatic conditions, the edaphic factor is the other essential issue that explains the current persistence of $P$. sylvestris in the Betic mountains. Although the biogeographical districts where the nevadensis subspecies appears have a predominance of very rocky and not overly developed basic lithosols over calcareous substrates -mainly Triassic limestones and dolomites-, its forests mostly occupy more evolved acidic soils -of eutric regosol type- that appear locally on siliceous substrates such as calc-schists, quartzites, and phyllites. In addition to the clear contrast in the degree of evolution between these basic and acidic edaphic domains, there is a remarkable difference in the ability to retain moisture between them .Compared to the high capacity of the basic soils for water percolation, which causes significant edaphic xericity, the acidic soils are relatively impermeable and even experience frequent flooding phenomena during the rainy season (autumn and winter) and spring thaw. Thus, in the most xeric enclaves, that is, in the rockiest soils of a carbonate nature and also in locations with less favourable microclimates (such as on the steepest slopes and on some of the highest, most storm-beaten peaks), P. sylvestris disappears quickly, especially in southern orientations, being gradually replaced by $P$. nigra Arnold subsp. latisquama (Willk.) Heywood in Oromediterranean level, and by P. pinaster Aiton, Quercus rotundifolia L., and Acer granatense Boiss. in Supramediterranean area. P. sylvestris also disappears in enclaves where the almost permanent seasonal soil waterlogging allows only the development of hygrophilous grasslands of Festuca iberica (Hack.) K. Richt., which are considered out of the plant succession of the forest.

\section{Plant dynamic and floristic composition of $P$. sylvestris subsp. nevadensis phytocoenosis}

The forests of $P$. sylvestris subsp. nevadensis integrate the Daphno hispanicae-Pinetum nevadensis association, which constitute the climax stage of the vegetation series Daphno hispanicae-Pinetonevadensis Sigmetum. This one is defined by Rivas-Martinez (2011) as the series of the forests of $P$. sylvestris subsp. nevadensis and Daphne oleoides Schreb. with Juniperus sabina L. and P. nigra subsp. latisquama, of limestone and dolomite nature, climatophilous and edaphoxerophilous character, and endemic to Sierra Nevada and Sierra de Baza. The climax community occurs on limestone-dolomite rocks and, although its bioclimatic optimum is the Oromediterranean zone, the series also appears in Supramediterranean enclaves due to topographical reasons that prevent the develop- 
ment of vegetation typical of this level, as Molero et al. (1992) have identified.

The climax stage is characterized by forests of heliophilous nature and simple stratification, denser on more humid, cooler slopes over siliceous substrates. In rock enclaves, the forest has a progressively more open configuration as a result of greater soil xericity, which causes the replacement of $P$. sylvestris by $P$. nigra subsp. latisquama, with a very limited coexistence of both species, which only occurs locally in Sierra de Baza. There is a predominance of mature trees, some very long-lived, reaching heights of more than $12 \mathrm{~m}$, and relatively few young individuals and seedlings. In addition to the forests, the climax is completed with creeping thickets of junipers of J. sabina (figure 3 left above) and creeping junipers of J. communis L. subsp. hemisphaerica (K. Presl) Nyman, which are scattered under the trees and on sparsely wooded or un-wooded slopes indistinctly, where they colonize even the rockiest soils with variable coverage. Phytosociological inventories show in detail the structure and floristic composition of the Daphno hispanicae-Pinetum nevadensis community (Table 1).

However, the marginal ecological boundary where the P. sylvestris subsp. nevadensis forests grow induce a plant ecosystem with a seriously degraded structure, characterized by serial vegetation stages, with a characteristic flora cohort (Table 2), that frequently replaces the climax communities:

Table 1. Structure and floristic composition of Daphno hispanicae-Pinetum nevadensis association (phytosociological inventories)

\begin{tabular}{|c|c|c|c|c|c|c|c|c|c|c|c|c|}
\hline Inventory №* & 1 & 2 & 3 & 4 & 5 & 6 & 7 & 8 & 9 & 10 & 11 & 12 \\
\hline Altitude (m asl x10) & 203 & 210 & 191 & 202 & 207 & 200 & 169 & 178 & 200 & 196 & 174 & 181 \\
\hline Vegetal cover & 85 & 65 & 80 & 55 & 90 & 85 & 80 & 60 & 70 & 75 & 70 & 75 \\
\hline Area $\left(\mathrm{m}^{2}\right)$ & 250 & 300 & 400 & 350 & 350 & 250 & 250 & 400 & 200 & 300 & 250 & 150 \\
\hline Orientation & $\mathrm{NE}$ & $\mathrm{N}$ & $\mathrm{N}$ & $S$ & $\mathrm{~N}$ & NE & $\mathrm{N}$ & NE & $\mathrm{N}$ & $\mathrm{N}$ & $\mathrm{NE}$ & $\mathrm{NE}$ \\
\hline Degree of slope (\%) & 5 & 15 & 10 & 15 & 5 & 5 & 5 & 20 & 10 & 15 & 10 & 20 \\
\hline \multicolumn{13}{|c|}{ Association characteristic taxa } \\
\hline $\begin{array}{l}\text { Pinus sylvestris } \\
\text { nevadensis }\end{array}$ & 4 & 3 & 2 & 3 & . & 1 & 4 & 3 & . & 3 & 3 & 1 \\
\hline Pinus nigra latisquama & . & . & 3 & 1 & + & . & . & . & . & . & . & . \\
\hline Juniperus sabina & 2 & 2 & 2 & 1 & 4 & 3 & 2 & 2 & 4 & 2 & 1 & 3 \\
\hline Juniperus hemisphaerica & 1 & $r$ & 1 & . & + & 2 & 1 & 1 & + & + & 1 & 3 \\
\hline Daphne hispanica & . & + & . & $r$ & $r$ & $r$ & 1 & + & . & . & + & + \\
\hline Poa ligulata & . & + & . & . & + & . & . & . & . & . & . & . \\
\hline \multicolumn{13}{|l|}{ Companion taxa } \\
\hline Acer opalus granatensis & + & . & + & . & . & & $r$ & + & . & . & . & + \\
\hline Berberis hispanica & 2 & 1 & 2 & 1 & 1 & 2 & 1 & 2 & 1 & 1 & 2 & 1 \\
\hline Vella spinosa & 1 & + & 1 & 1 & + & + & . & 1 & 1 & . & $r$ & + \\
\hline Hormathophylla spinosa & 1 & + & 1 & $r$ & + & + & + & . & + & . & + & + \\
\hline Rosa sicula & + & 1 & 1 & . & + & 1 & + & $\mathrm{r}$ & . & + & . & + \\
\hline Erinacea anthyllis & + & . & . & + & . & + & + & 1 & . & . & + & . \\
\hline Astragalus granatensis & + & + & 1 & . & + & 1 & $r$ & 1 & 1 & . & + & + \\
\hline Rosa pouzinii & $r$ & . & . & . & . & . & 1 & + & . & . & . & . \\
\hline Prunus ramburii & + & . & . & + & + & . & $r$ & . & + & . & $r$ & . \\
\hline Prunus prostrata & & - & & & + & . & . & $r$ & + & . & . & . \\
\hline Ononis aragonensis & + & . & $r$ & . & $r$ & . & 1 & 1 & + & . & + & . \\
\hline Amelanchier ovalis & . & $r$ & + & . & . & . & + & + & $r$ & . & . & + \\
\hline Crataegus monogyna & . & . & + & $r$ & . & $r$ & 1 & 2 & . & 2 & 1 & . \\
\hline Lonicera arborea & . & . & $r$ & . & . & $r$ & . & . & . & + & . & . \\
\hline Lonicera splendida & . & . & . & . & . & . & + & + & . & . & . & . \\
\hline Paeonia officinalis & . & . & . & . & . & . & . & $r$ & . & . & . & . \\
\hline $\begin{array}{l}\text { Hormathophylla } \\
\text { longicaulis }\end{array}$ & . & . & & . & . & & . & + & . & & . & \\
\hline Arenaria armerina & . & . & & . & . & & . & 1 & . & . & + & + \\
\hline
\end{tabular}


Pinus sylvestris L. subsp. nevadensis (Christ) Heywood in southern Spain:

An endangered endemic Mediterranean forest

\begin{tabular}{|c|c|c|c|c|c|c|c|c|c|c|c|c|}
\hline Inventory №* & 1 & 2 & 3 & 4 & 5 & 6 & 7 & 8 & 9 & 10 & 11 & 12 \\
\hline Festuca iberica & 1 & . & + & . & . & + & . & . & . & $r$ & . & + \\
\hline Festuca hystrix & 1 & 1 & 1 & + & + & 1 & . & 1 & + & . & . & 1 \\
\hline Festuca indigesta & + & + & 1 & . & + & 1 & . & . & . & . & . & + \\
\hline Digitalis obscura & $r$ & . & 1 & . & . & $r$ & $r$ & . & . & . & $r$ & . \\
\hline Saxifraga granulata & + & . & 1 & + & + & . & . & . & . & . & . & . \\
\hline Helictotrichon filifolium & . & + & + & . & . & . & + & + & + & . & + & + \\
\hline Cerastium gibraltaricum & . & . & $r$ & + & . & . & . & . & + & $r$ & . & + \\
\hline Polygala boissieri & . & . & . & . & . & . & . & + & + & . & + & . \\
\hline Koeleria vallesiana & . & . & . & . & . & . & + & $r$ & + & . & . & . \\
\hline Cotoneaster granatensis & . & . & . & . & . & . & + & . & . & . & . & . \\
\hline Euphorbia nevadensis & . & . & . & . & . & . & + & . & . & . & + & . \\
\hline Erysimum nevadensis & . & . & . & . & . & . & . & . & . & + & . & + \\
\hline Festuca scariosa & . & . & . & . & + & + & + & + & . & . & + & . \\
\hline Scabiosa turolensis & . & + & . & . & . & $r$ & . & . & . & . & . & . \\
\hline Jurinea humilis & . & . & . & . & $r$ & $r$ & . & . & + & . & . & . \\
\hline Tulipa sylvestris & . & . & & . & $r$ & . & . & . & . & . & . & . \\
\hline
\end{tabular}

Source: Authors (own elaboration)

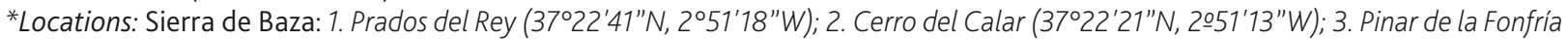

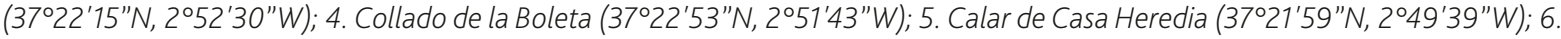

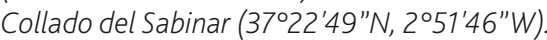

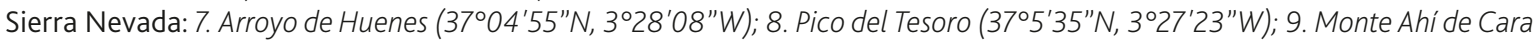

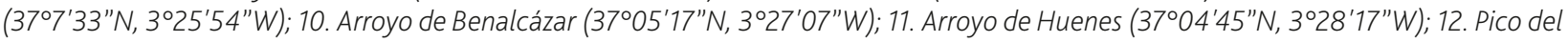
Tesoro $\left(37^{\circ} 5^{\prime} 28^{\prime \prime} \mathrm{N}, 3^{\circ} 27^{\prime} 30^{\prime \prime} \mathrm{W}\right)$.

Table 2. Main flora of the climax community and of the serial stages that integrate the plant succession of $P$. sylvestris subsp. nevadensis forests

\begin{tabular}{|c|c|}
\hline Vegetal stage & Associations and main taxa \\
\hline $\begin{array}{l}\text { Pinewoods } \\
\text { and creeping } \\
\text { thickets }\end{array}$ & $\begin{array}{l}\text { Daphno-Pinetum nevadensis. Characteristic species: P. sylvestris subsp. nevadensis, P. nigra subsp. latisquama, } \\
\text { Taxus baccata, Acer opalus subsp. granatensis, Juniperus sabina, J. communis subsp. hemisphaerica, Geum } \\
\text { heterocarpum, Hypericum hyssopifolium and Polygala boissieri. }\end{array}$ \\
\hline $\begin{array}{l}\text { Preforestal } \\
\text { thorny belt }\end{array}$ & $\begin{array}{l}\text { Lonicero-Berberidetum hispanicae sub-ass. juniperetosum sabinae. Characteristic species: Berberis hispanica, } \\
\text { Amelanchier ovalis, Crataegus monogyna, C. granatensis, Cotoneaster granatensis, Lonicera arborea, L. splendida, } \\
\text { Prunus prostrata, P. ramburii, Rhamnus saxatilis, Rosa stylosa, R. pouzinii, R. sicula, R. micrantha, R. pimpinellifolia } \\
\text { and Ononis aragonensis. }\end{array}$ \\
\hline $\begin{array}{l}\text { Xeroacanthic } \\
\text { thickets }\end{array}$ & $\begin{array}{l}\text { Festuco-Astragaletum granatensis (Sierra Nevada). Characteristic species: Hormathophylla spinosa, Astragalus } \\
\text { granatensis, A. vesicarius, Erinacea anthyllis subsp. anthyllis, Vella spinosa, Bupleurum spinosum, Daphne oleoides, } \\
\text { Prunus prostrata, Arenaria armerina subsp. caesia, Erysimum nevadense, Cerastium gibraltaricum, Euphorbia } \\
\text { nevadensis subsp. nevadensis, Acinos alpinus, Alyssum nevadense, Thesium humifusum, Teucrium similatum, } \\
\text { Jurinea humilis and Scabiosa turolensis. } \\
\text { Saturejo-Velletum spinosae (Sierra de Baza). Characteristic species: Hormathophylla spinosa, Astragalus } \\
\text { granatensis, A. vesicarius, Erinacea anthyllis subsp. anthyllis, Vella spinosa, Bupleurum spinosum, Daphne } \\
\text { oleoides, Prunus prostrata, Arenaria armerina subsp. caesia, Cerastium gibraltaricum, Euphorbia nevadensis subsp. } \\
\text { nevadensis, Acinos alpinus, Genista pseudopilosa, Thesium humifusum, Sideritis carbonellis, Teucrium similatum, } \\
\text { Jurinea humilis and Scabiosa turolensis. } \\
\text { Convolvulo-Andryaletum agardhii. Characteristic species: Pterocephalus spathulathus, Satureja intricata, } \\
\text { Hormathophylla longicaulis, Arenaria armerina subsp. armerina and A. tetraquetra subsp. murcica. }\end{array}$ \\
\hline $\begin{array}{l}\text { Serial } \\
\text { grasslands }\end{array}$ & $\begin{array}{l}\text { Coronillo-Astragaletum nummuraloides. Characteristic species: Ononis cristata, Astragalus incanus subsp. } \\
\text { nummuraloides, Coronilla minima, Plantago holosteum, Koeleria dasyphyllasubsp. dasyphylla, Festuca hyxtris, Carex } \\
\text { leporina, Dianthus brachyanthus, Poa ligulata, Jurinea humilis and Helianthemum oelandicum subsp. incanus. } \\
\text { Seselio-Festucetum hystricis. Characteristic species: Seseli montanum subsp. granatense, Festuca hystrix, Poa } \\
\text { ligulata, P. flaccidula, A. armerina, Koeleria vallesiana, Jurinea humilis, Odontites viscosus subsp. granatensis and } \\
\text { Alyssum serpyllifolium. }\end{array}$ \\
\hline
\end{tabular}

Source: Based on the fieldwork and previous studies of Valle and Gómez (1988), Blanca and Morales (1991), Valle (2003) and OlmedoCobo (2011) 
Preforestal belt. The first serial stage corresponds to thorny thickets of usually modest height ( 0.5 to $1.5 \mathrm{~m}$ ) and variable coverage, which occupy the peripheral areas around forests and clearings inside them (figure 3 right above). This stratum is progressively less dense on the rockier, steeper slopes due to greater soil xericity. This community belongs to the Lonicero splendidaeBerberidetum hispanicae association which, although it has a Supramediterranean optimum, also grows in the lower horizon of the Oromediterranean level, where it is designated as juniperetosum sabinae sub-association (junipers and creeping junipers differentiate it from the Supramediterranean typical stage).

Xeroacanthic thickets. Spiny formations well adapted to high-mountain mesological conditions. These communities grow mostly in the driest, rockiest, and most eroded soils and in places very exposed to wind and solar radiation, where they replace the forests, creeping thickets, and preforestal thorny belts (figure 3 left bottom). This stage has a different taxonomic classification in the Granadino-Almijarense
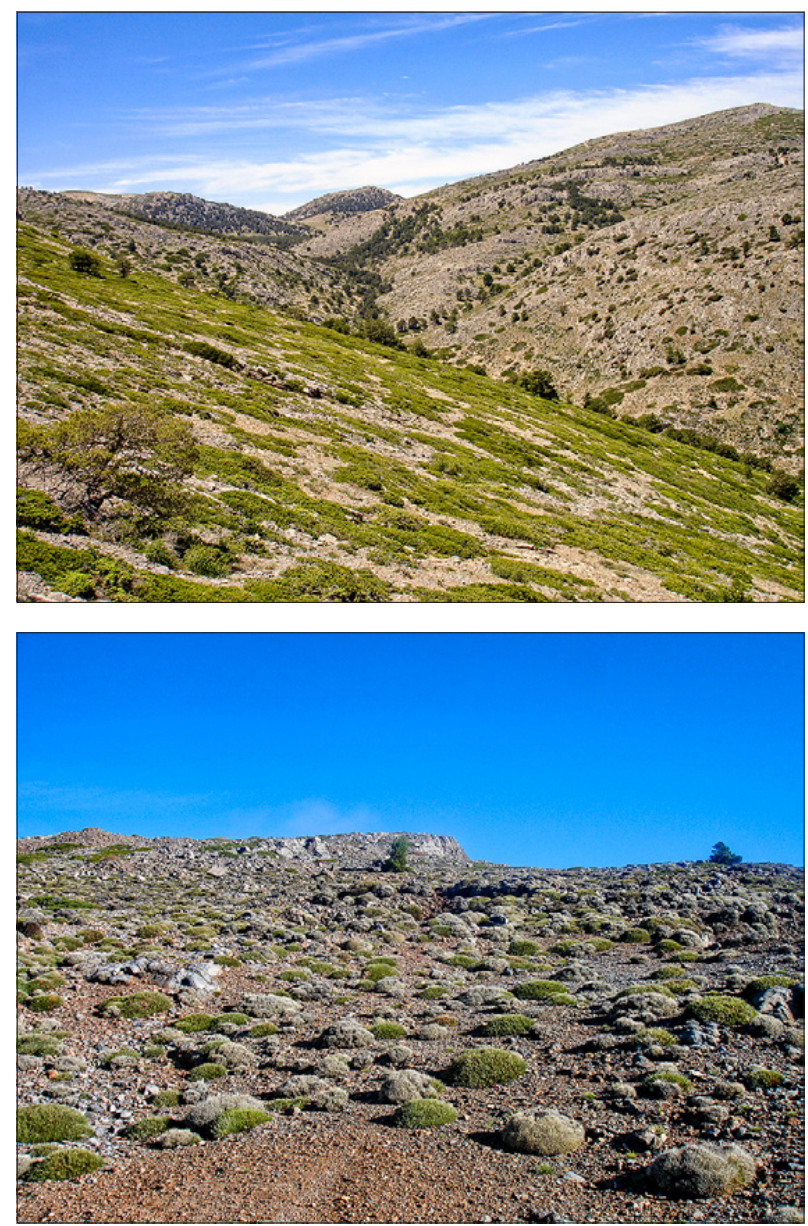

and Accitano-Bastetano sectors: the community is known as Festuco hystricis-Astragaletum granatensis in Sierra Nevada, while in Sierra de Baza it is classified as Saturejo intricatae-Velletum spinosae association. Finally, endemic thyme formations of small size and open cover appear locally located over sandy soils (with superficial fragmentation of dolomitic rocks), belonging to the Convolvulo nitidi-Andryaletum agardhii association.

Serial grasslands. Two main stages of serial grasslands can be differentiated in the plant succession of Daphno-Pinetum nevadensis depending on the development and moisture-holding capacity of the soils. First, Oromediterranean grasslands of a perennial character (Coronillo minimae-Astragaletum nummuraloides) develop in the most evolved basic soils, which hold moisture in spring and until the beginning of the dry season (parching during the summer), especially in topographically and geomorphologically favourable enclaves such as karst depressions (figure 3 right bottom). The second formation corresponds to
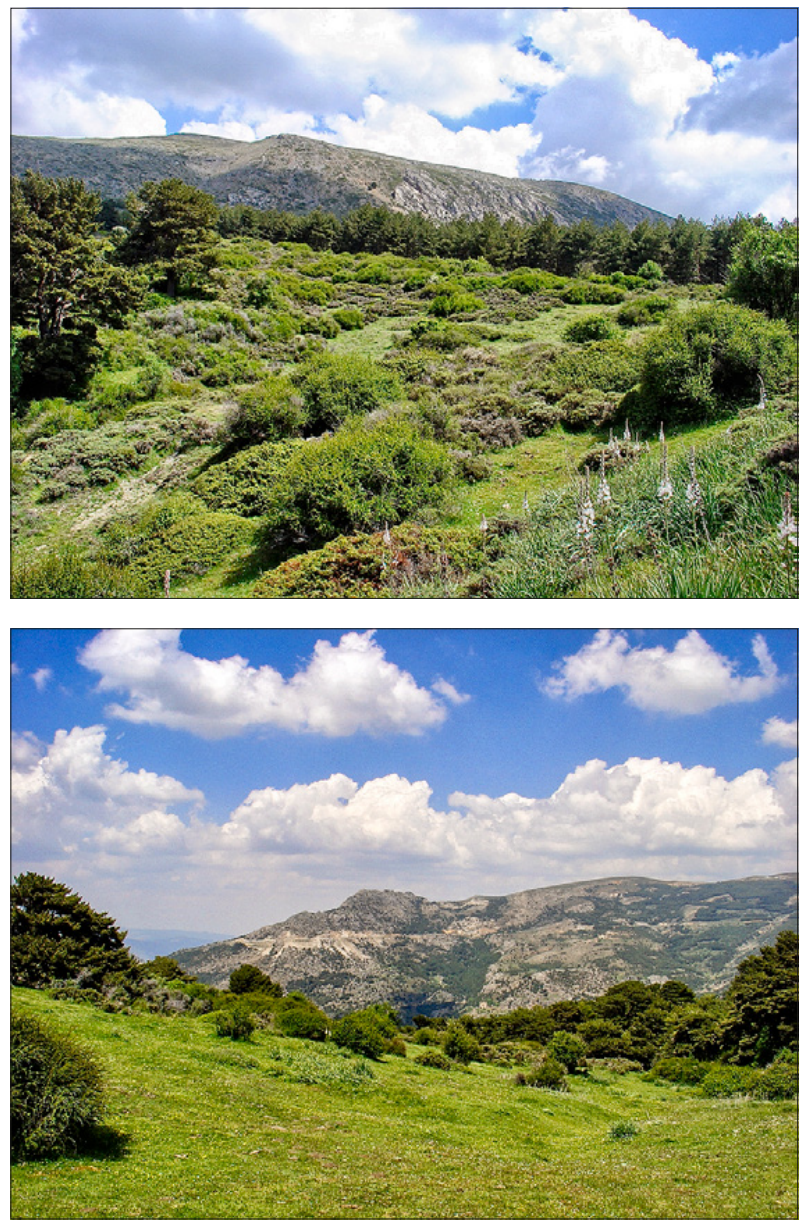

Figure 3. Creeping thickets of $J$. sabina colonizing the most rocky and xerophytic slopes (Santa Bárbara peak, Sierra de Baza) (left above); Preforestal thorny belt of the P. sylvestris subsp. nevadensis forests in Collado de Matas Verdes (Sierra Nevada) (left right); Spiny scrub of Hormathophylla spinosa (L.) P. Kupfer, Erinacea anthyllis Link ssp. anthyllis and Vella spinosa Boiss. in Calar de Rapa (Sierra de Baza) (left bottom); Serial grassland of Coronillo minimae-Astragaletum nummuraloides near the Tesoro peak (Sierra Nevada) (right bottom)

Source: Olmedo-Cobo 
grasslands with small grasses and low soil coverage, which grow in rocky enclaves of high xericity (Seselio granatensis-Festucetum hystricis).

P. sylvestris subsp. nevadensis forests comprise the upper wooded strip in the vegetation geoseries of the northern slopes of Sierra Nevada and Sierra de Baza (Figure $4 \mathrm{AB}$ ), and constitute the highest treeline boundary in the Betic Cordillera. These pinewoods can be considered a transitionary woodland domain between the temperate forests occupying the middle Betic mountain [Mesomediterranean and Supramediterranean sclerophyllous and coniferous forests of $Q$. rotundifolia, Q. Faginea Lam., Q. Pyrenaica Willd., P. pinaster, P. halepensis Mill. and P. nigra, and locally Supramediterranean deciduous forests of $A$. monspessulanum L., A. opalus subsp. granatensis, Sorbus aria
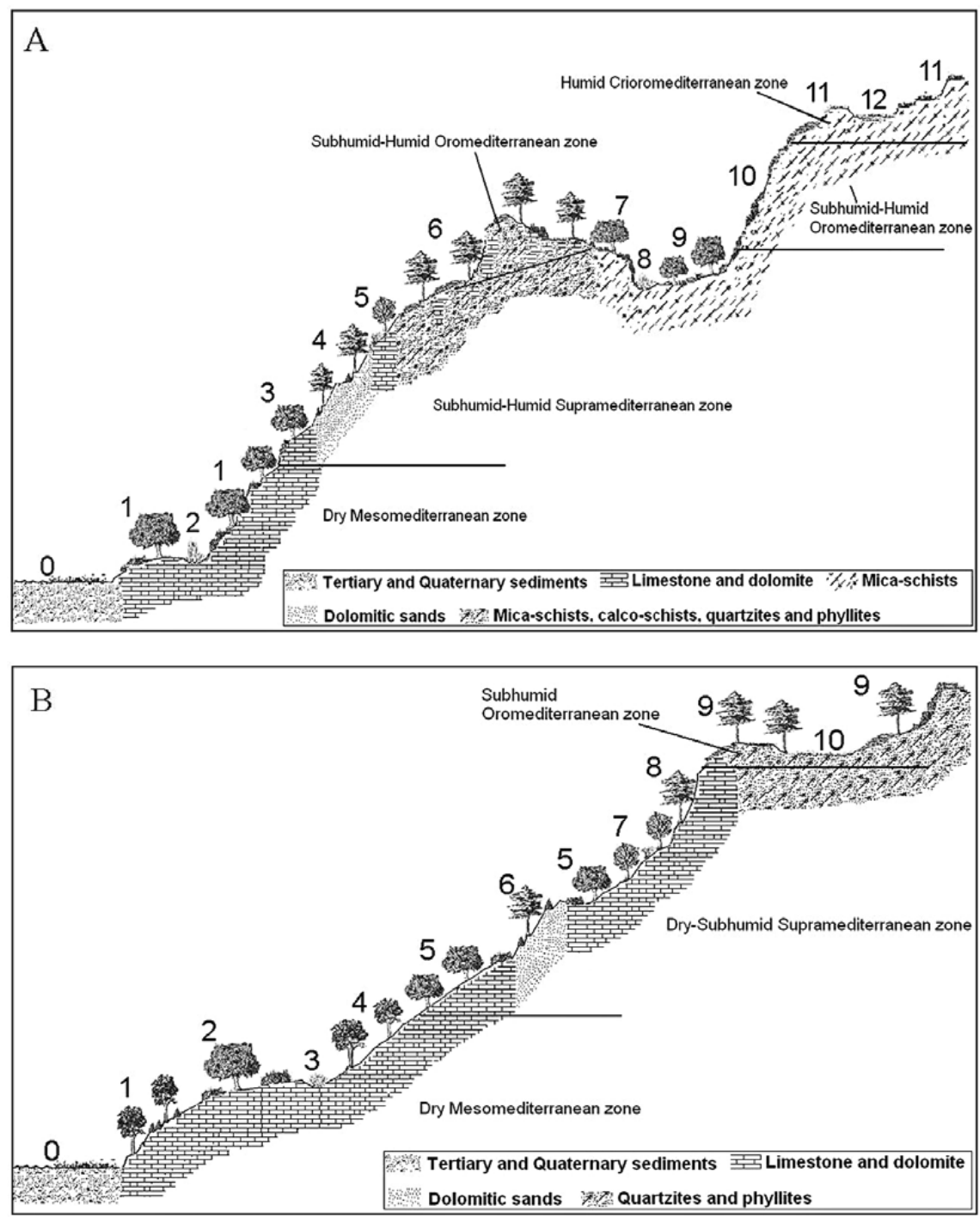

Figure 4. Position of $P$. sylvestris subsp. nevadensis forests in the vegetation geoseries of the northern slope of (A) Sierra Nevada and (B) Sierra de Baza Source: Authors

(A): 0, Anthropogenic areas without vegetation. 1, Climatophilous forests of Quercus rotundifolia. 2, Edaphohygrophilous riparian formations of Salix and Populus. 3, Climatophilous forests of Q. rotundifolia. 4, Edaphoxerophilous forests of P. pinaster. 5, Climatophilous forests of Acer granatensis. 6, Climatophilous forests of P. sylvestris subsp. nevadensis. 7, Climatophilous forests of Q. rotundifolia. 8, Edaphohygrophilous riparian formations of Carex and Salix. 9, Climatophilous forests of Q. pyrenaica. 10, Creeping and xeroacanthic scrubs. 11, Psicroxerophilous grasslands. 12, Edaphohygrophilous geopermaseries.

(B): 0, Anthropogenic areas without vegetation. 1, Edaphoxerophilous forests of P. halepensis. 2, Climatophilous forests of Q. rotundifolia. 3, Edaphohygrophilous riparian formations of Salix and Populus. 4, Sub-spontaneous pinewoods of P. halepensis. 5, Climatophilous forests of Q. rotundifolia. 6, Edaphoxerophilous forests of P. halepensis. 7, Climatophilous forests of A. granatensis. 8, Edaphoxerophilous forests of P. latisquama. 9, Climatophilous forests of $P$. sylvestris subsp. nevadensis. 10, Edaphohygrophilous geopermaseries. 
(L.) Crantz, S.torminalis (L.) Crantz, Alnus glutinosa, and Betula pendula Rothsubsp. fontqueri (Rothm.) G. Moreno \& Peinado] and the un-wooded Mediterranean cold-steppe vegetation that grows above 2.00o$2.200 \mathrm{~m}$ asl (creeping thickets mainly of J. sabina, J. communis subsp. hemisphaerica, Genista versicolor Boiss. and Cytisus galianoi Talavera \& Gibbs, and, above all, steppes of Festuca genus).

\section{Cartography of current and potential area of forests}

The potential distribution area of $P$. sylvestris subsp. nevadensis reaches $13.32 \mathrm{~km}^{2}$ in Sierra Nevada and
$29.71 \mathrm{~km}^{2}$ in Sierra de Baza (Figure 5). In both cases, it is difficult to calculate accurately how much of the phytocoenosis domain is occupied at present by indigenous pinewoods due to the reforestation carried out in the 1950s and 1960s, which has greatly denaturalized the plant ecosystem. As a result, the coverage of the potential surface area by natural forests at present is minimum: it has been established that only $2.17 \mathrm{~km}^{2}$ in Sierra Nevada (localized on the south-western core of the subspecies nevadensis potential area, Figure $6 \mathrm{~A}$ ) and $5.12 \mathrm{~km}^{2}$ in Sierra de Baza (Figure $6 \mathrm{~B}$ ) are forests with an arboreal cover of adult specimens mostly

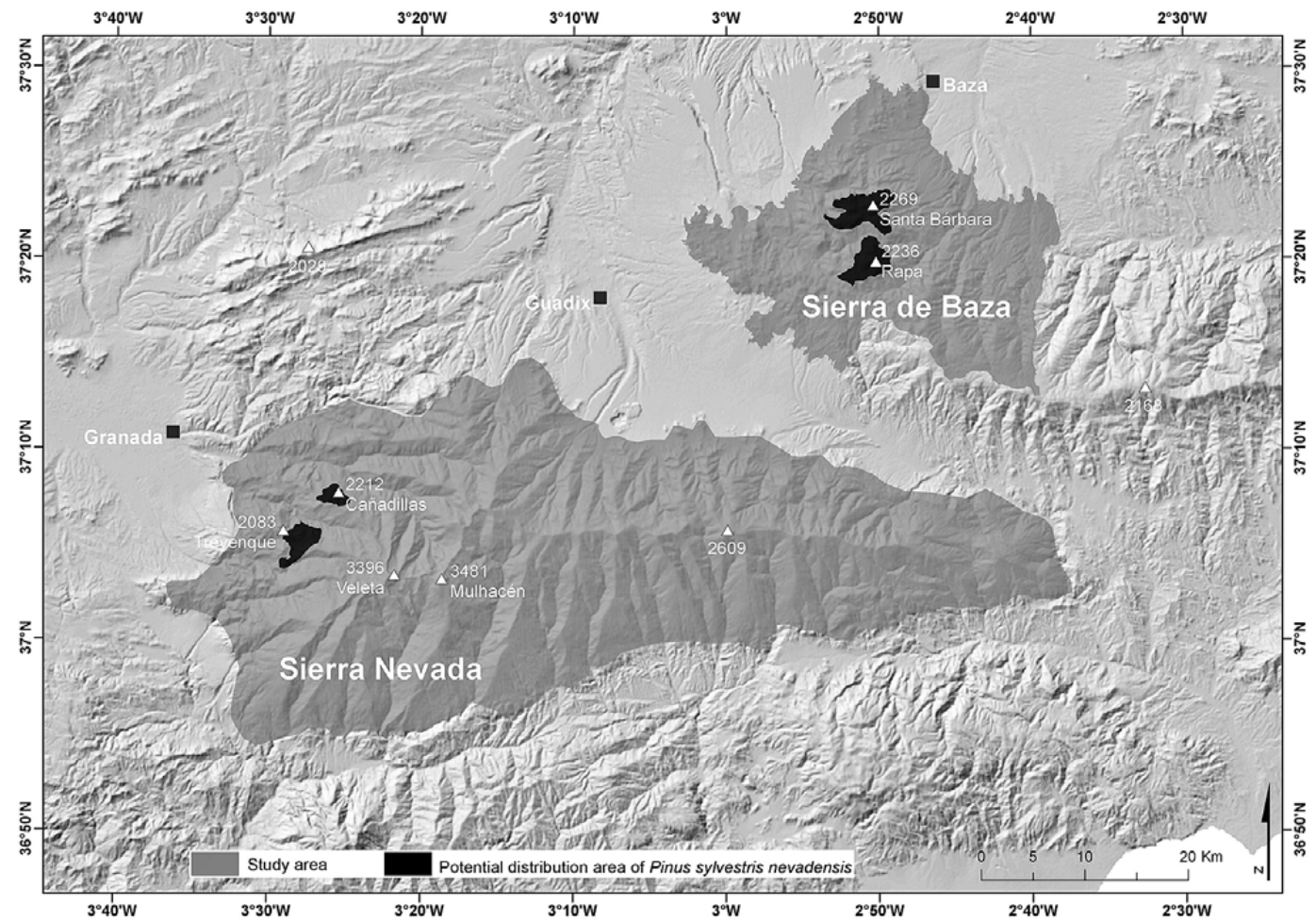

Figure 5. Potential distribution area of $P$. sylvestris subsp. nevadensis in Sierra Nevada and Sierra de Baza Source: Based on fieldwork and modified from Valle and Gómez (1988), Valle (2003) and Olmedo-Cobo (2011)
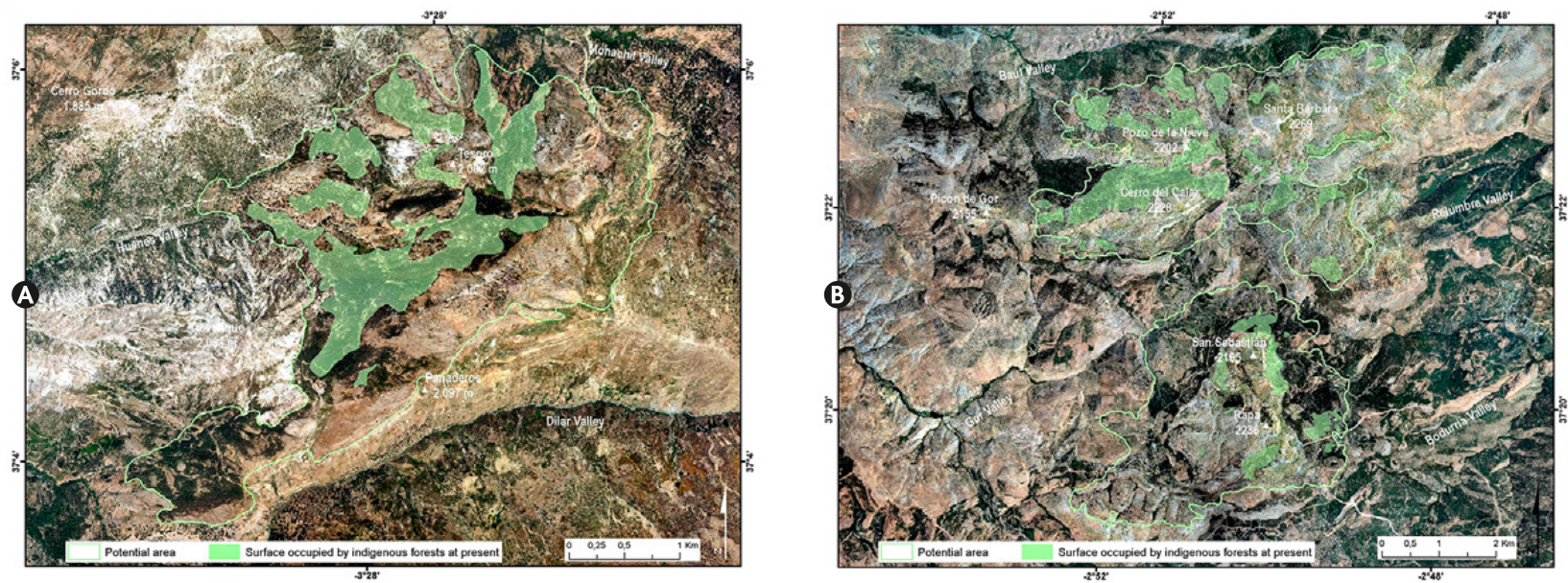

Figure 6. Current surface occupied by indigenous forests of $P$. sylvestris subsp. nevadensis in Sierra Nevada (A) and Sierra de Baza (B)

Source: Based on fieldwork and modified from Valle and Gómez (1988), Valle (2003) and Olmedo-Cobo (2011) 
native $(>60 / 80 \%)$. The rest of the potential area is occupied by afforestation masses of Pinus (sylvestris, nigra, pinaster) or by replacement stages of the climax, among which stands out the scrubs of J. sabina and $J$. communis due to its ecological role of providing nurse formations for pine seedlings.

\section{Discussion}

The natural regression related to climate evolution after the last glacial maximum and human-induced degradation of the P. sylvestris subsp. nevadensis forests by agriculture, overgrazing, mining, and forestry in the Betic Cordillera during the last centuries a reality. The presence of refugees of this species in two southern Iberian Peninsula massifs is undoubtedly related to the existence of benign microenvironments in these mountains, which may lead to the species being included in the group of European tree species whose local climatic shelter at their range limit is still associated with glacial refuges (Tzedakis et al., 2002; Svenning, Skov, 2007). As pointed out by Linares (2011) for the Mediterranean firs (Abies genus), the orographical complexity of the Mediterranean region has presumably also played a key role in the evolution and persistence of $P$. sylvestris forests in southern phyto-refuges, such as the Betic Cordillera, after the last glaciation.

From the data collected during this research, the main key to the persistence of $P$. sylvestris subsp. nevadensis seems to be the edaphic factor. Fieldwork has found that the main forests grow over partially acidic soils (in a mainly calcareous lithological environment in both massifs), allowing the species to tolerate the dryness of the summer period; this warm season is characterized by high sunshine and a notable absence of rainfall in July and August and also often in June and September, with less than $10 \mathrm{~mm}$ of rain in the driest month (Costa, et al., 2005). This partial development of $P$. sylvestris subsp. nevadensis on acidic soils means that the edaphic character of the series Daphno-Pineto nevadensis must be redefined, and be considered as silicicolous and not only as limestone and dolomiticolous. In addition, due to its strong Mediterranean character it is predictable that the subsp. nevadensis is better adapted to the conditionings (warm, dryness and drought) of the Mediterranean climate of southern Iberian Peninsula than other northern Iberian varieties located in mountain areas that keep Eurosiberian ecological conditions. Martínez-Vilalta and Piñol (2002) and Hódar et al. (2003) point out that Spanish populations of $P$. sylvestris suffered high mortality rates associated with years of drought during 2005-2007; however, evidence has not been found to suggest that this climate event (with precipitation rates of between $25 \%$ and $75 \%$ below normal in the
Betic Cordillera) has affected the subsp. nevadensis, with an abnormal death rate not having been detected.

However, the future is uncertain and the above hypothesis may prove unreliable if the forecasts that announce lower rainfall totals and more extreme periods of drought come true (Morata, 2014). This fact is more relevant considering that the Mediterranean $\mathrm{Ba}$ $\sin$ is one of the world's most vulnerable regions to the global environmental threat, that it is already being affected by climate change (Giorgi, 2006), which will have numerous potential effects and will be a major driving factor in mountain ecosystem development in the next century (Jentschs, Beierkuhnlein, 2003; Löffler, et al., 2011). The alteration of conditions at a local level can be lethal for P. sylvestris subsp. nevadensis, which can be replaced by $P$. nigra (Benito, et al., 2006; Garzón, et al., 2008) due to the better adaptation of this species to the continental and relatively xeric conditions of the Betic Cordillera climate, something that is also expected to happen in other northern mountains of the Iberian Peninsula (Ruiz-Labourdette, et al., 2012). López and Camacho (2010) have estimated an $85 \%$ decline in the potential area of $P$. sylvestris in Spain, dropping from $84,447 \mathrm{~km}^{2}$ under current climate conditions to only $12,691 \mathrm{~km}^{2}$ under the predicted conditions in 2050 (based on the regionalised scenarios of climate change on Spain, Morata, 2014). Regarding the predicted warming in this area of the planet, Vandvik (2017) points out that temperature alone should not be used to predict the future evolution of tree seedling establishment above the alpine treeline, so extrapolations from climate envelope models could strongly over or under estimate the upper forest boundary responses to global change.

It is too early to accurately predict the future of $P$. sylvestris subsp. nevadensis because it is not possible to know the species current (and future) adaptation to adverse climatic conditions and global change, in particular in these mountain environments that are now subject to less anthropogenic alteration in recent decades, especially over the last 25 years as result of the new protected status of Sierra Nevada (Natural Park and National Park) and Sierra de Baza (Natural Park). The circumstances in which these forests evolve are just beginning to be understand. In this regard, future knowledge of these mountain areas should take into account the arguments of Löffler et al. (2011), that whilst many detailed studies have generated highly specific data related to the response mechanisms to global change in mountain areas, these results are often obtained under a narrow range of environmental conditions; in the study area, e.g., the climatic data collected above $2.000 \mathrm{~m}$ asl in Sierra Nevada are insufficient (only 20 years of observations at best) and, in some cases, unreliable, while in the upper part of 
the Sierra de Baza there is no climatic information beyond data obtained from extrapolations, such as those collected in Olmedo-Cobo (2011). Thus, it is necessary for multi-factorial studies in order to understand the interplay between the processes of climatic change and other environmental factors, and their effects on tree seedling establishment across the upper boundaries of the current forest (Vandvik, 2017).

In this uncertain climatic scenario, the most negative factor for the current survival of the subsp. nevadensis in the geographical context of Betic mountain range is the long and complex process of natural regeneration of P. sylvestris in Mediterranean environments, which is not successful in all cases (GonzálezMartínez, Bravo, 1999; Koski, 2000); especially at risk is recruitment at its southern most edge due to the predicted increase in summer drought (Escudero, et al., 1997; Martínez-Vilalta, Piñol, 2002; Castro, et al.,2004). Other serious obstacles to the conservation and development of seeds, seedlings, and juve- investigation have verified how in winter of 2016 the pest has reached levels above $2,000 \mathrm{~m}$ asl affecting autochthonous masses of $P$. sylvestris (and P. nigra) of Sierra de Baza, so this factor may has contributed to the death of numerous trees already weakened by the drought that has affected this area in recent years (Figure 7 left) (Olmedo-Cobo, et al., 2016). In addition, this process of forest decay has also been aggravated by the presence -observed by the authors during spring and summer of 2016- of bark beetle (Tomicus genus, subfamily Scolytinae) causing a remarkable mortality of pine trees in low and medium zones of this massif (Figure 7 right), pest that threatens to also affect the forests of $P$. sylvestris subsp. nevadensis in the upper zone of the massif.

In addition, the reforestation carried out from the 1950 s to the 1980 os is another important obstacle for the regeneration and conservation of P.sylvestris subsp. nevadensis forests. This process is in part the result of the abandonment of rural Mediterranean moun-
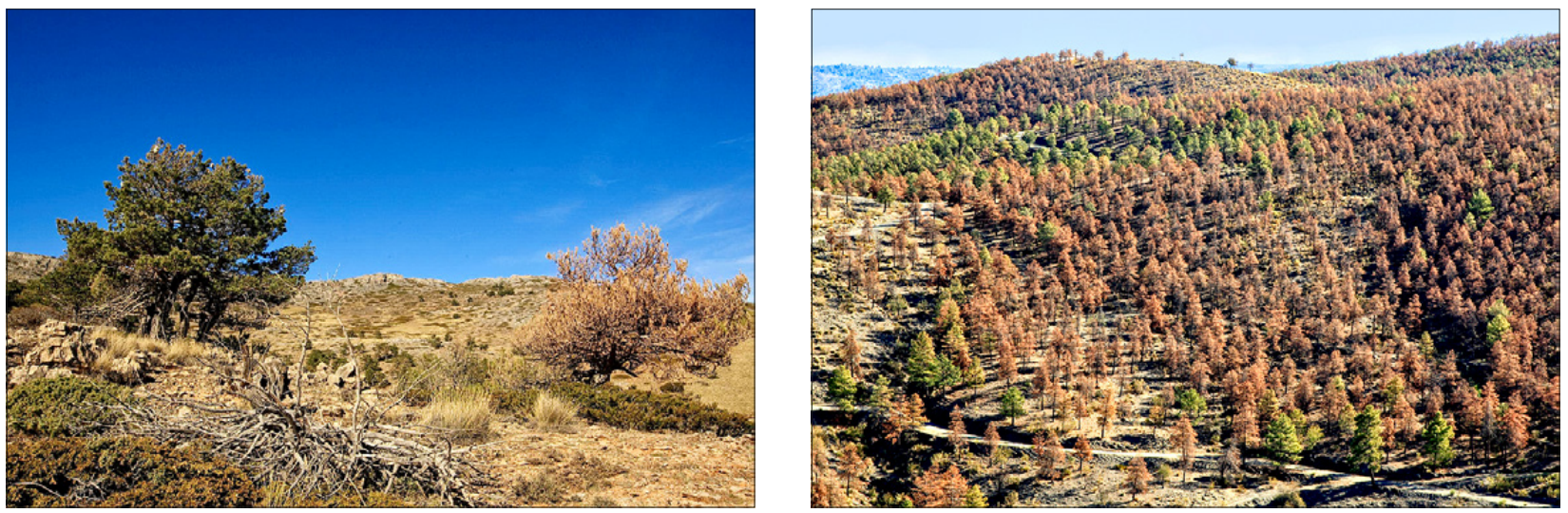

Figure 7. P. sylvestris subsp. nevadensis affected by T. pityocampa (left) and extensive masses of reforestation pines dead due to the action of Tomicus genus insects (right) in Sierra de Baza Source: Rodríguez-Sánchez

nile individuals, which ensure forest renewal, are the frequent presence of wild ungulate herbivores (mainly Cervus elaphus L.) and livestock herds in the study area -the pressure from animals is significantly high during dry season- (Castro, 1999; Zamora, et al., 2001; Castro, et al., 2004, 2005). Other causes of mortality of young seedlings are insect attacks, small landslides on steep slopes, consumption of seeds by rodents, and hail storms or frost out of season (Castro, et al., 2004, 2005). Especially important is the attack of Thaumetopoea pityocampa D. \& Schiff (pine processionary caterpillar); although it is worth noting that whilst this pest affects to a much greater extent the masses of conifers located between 800 and 1,500 m asl (Hódar, et al., 2003b), its effects over subsp. nevadensis are increasingly frequent as a result of climate change, and in spite of the isolation of these forests in high areas (Hódar, et al., 2003a). In fact, the authors of this tain areas (Sierra de Baza, for example, was extensively cultivated from its base up to about $2,000 \mathrm{~m}$ asl until the mid-twentieth century), which has caused significant repercussions for the environment and landscape, and severe social and economic differences between marginal agricultural areas of mountain and cities as a consequence of differential capitalist development (Sancho-Reinoso, 2013). The main problems in the Betic range are the occupation of the subsp. nevadensis habitats by artificial populations of pines and the genetic introgression that the planted species induce in the relict forests. Robleto et al. (2009) have established based on DNA-marker analysis of autochthonous $P$. sylvestris an average male gametic introgression rates from allochthonous plantations of 12,1 to $14,3 \%$ among naturally regenerated recruits in $\mathrm{Si}-$ erra Nevada (there are no studies of this type for the populations of Sierra de Baza). Due to the importance 
of pollen gene flow in homogenizing populations on this type of geographic scales (Pazouki, 2015), the genetic conservation management plans should include assisted regeneration and the maintenance of ex-situ germplasm collections.

Finally, the communities as a whole that comprise the phytocoenosis preserve numerous endemic species, some of which (including P. sylvestris subsp. nevadensis) are among the most endangered Mediterranean flora, especially those with a small chorological area that only appear in the Betic biogeographical province. Therefore, these forests have a "protective" role that favours the growth and conservation of part of these taxa. Due to all these circumstances, Sierra Nevada and Sierra de Baza can be included in the Mediterranean core refuges of plants in which the preservation of the most endangered species should be a priority to ensure their future persistence and genetic diversity (Médail, Diadema, 2009). These protectionary needs have been also remarked on by several other pieces of research exploring other relict peri-Mediterranean mountain and endangered species in Betic Cordillera, such as Abies pinsapo Boiss. by Olmedo-Cobo et al. (2017) and Gómez-Zotano et al. (2014), and Taxus baccata L. by Olmedo-Cobo and Gómez-Zotano (2014).

\section{Conclusion}

The exceptional and relict character of $P$. sylvestris subsp. nevadensis endemic forests is related both with the physical characteristics of the microenvironments in which the subspecies has taken refuge, as with the small size of its populations, the lack of regeneration and the absence of young specimens due to overgrazing. The cool, relatively moist climate in the higher areas of the Betic Cordillera, in particular in Sierra Nevada and Sierra de Baza massifs, the favourable $\mathrm{N}$ orientation and exposure to more humid air masses from the $\mathrm{W}$, and the relatively impermeable soils that the forests occupy are the main natural factors that have allowed the survival of $P$. sylvestris in the southern Iberian Peninsula under hostile Mediterranean environment conditions. Additionally, the natural process of regression and cantonment of the subsp. nevadensis forests in these disjunct and refuge areas, inside favourable ecological niches of upper treeline boundary, has been accelerated and strengthened in the last millennia by the intense anthropo-zoogenic disturbance to which these mountains have been subjected, within the broader context that has affected the Mediterranean basin. Thus, the human factor has decisively contributed to the uniqueness, rarity and endangered status of $P$. sylvestris subsp. nevadensis at present.
Given these circumstances, these forests can be considered as post-glacial relicts well adapted to the singular ecological Mediterranean conditions existing in the upper boundary treeline of Sierra Nevada and Sierra de Baza. This fact is especially important given the vulnerability of the Mediterranean Basin to predicted environmental changes; if the trend to warmer, drier climate conditions continues, this type of phytocoenosis will be the first to be in serious danger. Therefore, the protection of these high mountain Mediterranean forests threatened with extinction is particularly important.

In order to design meaningful plans for protecting these relict ecosystems, it is necessary to start solid programmes for monitoring the evolution of $P$. sylvestris subsp. nevadensis and studying the processes that make this species so unique and valuable. This also requires a broader knowledge of the ecological role of the biodiversity in the territory, because a less pluralistic area-based strategy (e.g. flora micro-reserves) for isolated species that are not strongly functionally connected to other taxa would be more effective than a National or Natural Park. Nonetheless, the declaration in past decades of these massifs as protected areas has provided a necessary, ideal, and unique support for the study, the management, and the protection of the P. sylvestris subsp. nevadensis relict forests in southern Spain.

\section{Acknowledgements}

Authors would like to acknowledge to Rich Gorman (PhD Researcher of the School of Geography and Planning - Cardiff University) by the English review of this paper.

\section{References}

Allué, J. L. 1990. Phytoclimatic atlas of Spain: taxonomies. Ministry of Agriculture, Fisheries and Food, Madrid, 221 pp. (in Spanish)

Andreu, L., Gutiérrez, E., Macias, M., Ribas, M., Bosch, O., Camarero, J. J. 2007. Climate increases regional tree-growth variability in Iberian pine forests. Global Change Biology 13, 804-815.

Benito, M., Blazek, R., Neteler, M., Sánchez de Dios, R., Sáinz, H., Furlanello, C. 2006. Predicting habitat suitability with machine learning models: the potential area of Pinus sylvestris in the Iberian Peninsula. Ecological Modelling 197, 383-393.

Blanca, G., Morales, C. 1991. Flora of the Sierra de Baza Natural Park. University of Granada, Granada, 381 pp. (in Spanish)

Blanca, G., Cabezudo, B., Cueto, M., Salazar, C., Morales, C. [eds.]. 2011. Vascular Flora of Eastern An- 
dalucia. Ministry of Environment of the Andalucia Government, Sevilla, 1,751 pp. (in Spanish)

Braun-Blanquet, J., Lalucat, J., De Bolós, O. 1979.Phytosociology. Bases for the study of the vegetal communities. Blume, Madrid, 820 pp. (in Spanish)

Castro, J. 1999. Regeneration dynamic of the native pine forests of scot pine (Pinus sylvestris nevadensis) of Sierra Nevada and Sierra de Baza. Unpublished PhD thesis, University of Granada, Granada, Spain. (in Spanish)

Castro, J., Zamora, R., Hódar, J. A., Gómez, J. M. 2004. Seedling establishment of a boreal tree species $(\mathrm{Pi}-$ nus sylvestris) at its southernmost distribution limit: consequences of being in a marginal Mediterranean habitat. Journal of Ecology 92, 266-277.

Castro, J., Zamora, R., Hódar, J.A.,Gómez, J. M. 2005. Ecology of seed germination of Pinus sylvestris at its southern, Mediterranean distribution range. Investigación Agraria: Sistemas y Recursos Forestales 14-2, 143-152.

Amaral, J. M. 1993. Iberian flora. Vascular plants of the Iberian Peninsula and Balearic islands Vol. 1. Royal Botanical Garden-Superior Centre of Scientific Researchs, Madrid. Available online: http://www.floraiberica.es/organizacion/planobra.php\#Volumen1 (17.06.2016)

Cheddadi, R., Vendramin, G. G., Litt, T., François, L., Kageyama, M., Lorentz S., Laurent, J. M., De Beaulieu, J. L., Sadori, L., Jost, A., Lunt, D. 2006. Imprints of glacial refugia in the modern genetic diversity of Pinus sylvestris. Global Ecology and Biogeography 15, 271-282.

Costa, M., Morla, C., Sáinz, H. [eds.]. 2005. The Iberian forests-A geobotanical interpretation. Planeta, Barcelona, 598 pp. (in Spanish)

Escudero, A., Barrero, S. Pita, J. M. 1997. Effects of high temperatures and ash on seed germination of two Iberian pines (Pinus nigrasalzmannii, P. sylvestrisiberica). Annales des Sciences Forestieres 54, 553562.

Garzón, M. B., Sánchez de Dios, R. S., Sáinz, H. 2008. The evolution of the Pinus sylvestris area in the Iberian Peninsula from the last glacial maximum to 2100 under climate change. Holocene 18-5, 705-714.

Giorgi, F. 2006. Climate change hot-spots. Geophysical Research Letters 33, Lo8707, Available online: doi: 10.1029/2006GLo25734 (3.12.2016).

Gómez-Zotano, J., Román, F., Hidalgo, N., PérezLatorre, A. V. 2014. Biodiversity and Conservation Values of Serpentine Ecosystems in Spain: Sierra Bermeja (province of Málaga). Boletín de la Asociación de Geógrafos Españoles 65, 187-206. (in Spanish)

González-Martínez, S. C. Bravo, F. 1999. Natural regeneration, establishment and first development of the scot pine (Pinus sylvestris). Investigación Agraria: Sistemas y Recursos Forestales 1, 225-247. (in Spanish)

Hódar, J. A., Castro, J., Zamora, R. 2003a. Pine processionary caterpillar Thaumetopoea pityocampa as a new threat for relict Mediterranean Scots pine forests under climatic warming. Biological Conservation 110, 123-129.

Hódar, J. A., Zamora, R., Castro, J. 2003b. The global change and the alteration of the ecological interactions: old pine not resist new pest. Quercus 210, 26-32.

Jentschs, A., Beierkuhnlein, C. 2003. Global climate change and local disturbances regimes as interacting drivers for shifting altitudinal vegetation patterns. Erdkunde 57, 216-231.

Kelly, D. L., Connolly, A. 2000. A review of the plant communities associated with Scots pine (Pinus sylvestris) in Europe, and an evaluation of putative indicator/specialist species. Investigación Agraria: Sistemas y Recursos Forestales 1, 15-39.

Koski, V. 2000. A note on genetic diversity in natural populations and cultivated stands of Scots pine ( $P i-$ nus sylvestris). Investigación Agraria: Sistemas y Recursos Forestales 1, 89-95.

Löffler, J., Anschlag, K. A., Baker, B., Finch, O. D., Diekkrüger, B., Wundram, D., Schröder, B., Pape, R., Lundberg, A. 2011. Mountain ecosystem response to global change. Erdkunde 65-2, 189-213.

López, J. M.,Camacho, C. A. 2010. Effects of climate change on the distribution of Pinus sylvestris stands in Spain. A phytoclimatic approach to defining management alternatives. Forest Systems 193, 329-339.

Linares, J. C. 2011. Biogeography and evolution of Abies (Pinaceae) in the Mediterranean Basin: the roles of long-term climatic change and glacial refugia. Journal of Biogeography 38, 619-630.

MacAllister, S. L. 2016. Regeneration of Scots pine (Pinus sylvestris L.) under drought. Unpublished $\mathrm{PhD}$ thesis, University of Edinburgh, Edinburgh, United Kingdom.

Martínez-Vilalta, J., Piñol, J. 2002. Drought-induced mortality and hydraulic architecture in pine populations of the NE Iberian Peninsula. Forest Ecology and Management 161, 247-256.

Martínez-Vilalta, J., López, C., Adell, N., Badiella, L., Ninyerola, M. 2008. Twentieth century increase of Scots pine radial growth in NE Spain shows strong climate interactions. Global Change Biology 14, 2,868-2,881.

Mason, W. L.,Alía, R. 2000. Current and future status of Scots pine (Pinus sylvestris) forests in Europe. Investigación Agraria: Sistemas y Recursos Forestales $1,317-335$. 
Médail, F., Diadema, K. 2009. Glacial refugia influence plant diversity patterns in the Mediterranean Basin. Journal of Biogeography 36, 1,333-1,345.

Molero, J., Pérez, F.,Valle, F. 1992. Natural Park of Sierra Nevada. Rueda, Madrid, 520 pp. (in Spanish)

Morata, A. 2014. Guide to regional scenarios of climate change on Spain based on the results of the IPCC-AR4. State Agency of Meteorology, Madrid, 197 pp. (in Spanish)

Olmedo-Cobo, J. A. 2011. Biogeographical Analysis and Mapping of the Sierra de Baza Vegetation (province of Granada). The current status of the phytocoenoses of an intensely humanized Mediterranean mountain. Unpublished $\mathrm{PhD}$ thesis, University of Granada, Granada, Spain. (in Spanish)

Olmedo-Cobo, J. A., Gómez-Zotano, J. 2014. The yew in southern Spain: geoecological analysis and proposal for the conservation of a Mediterranean population in critical danger of extinction. Bosque 35-1, 23-36. (in Spanish with English summary)

Olmedo-Cobo, J. A., Gómez-Zotano, J., Molero-Mesa, J. 2014. Biogeographical and phytosociological synthesis of the vegetation of Sierra de Baza Natural Park (Betic Cordillera, Andalucia, southern Spain). Estudios Geográficos 75-277, 649-682. (in Spanish)

Olmedo-Cobo, J. A., Serrano-Montes, J.L., RodríguezSánchez, J.A. 2016. Ecological crisis in the Oromediterranean pine forests of the Sierra de Baza (Betic Cordillera, Spain): the pests of Thaumetopoea pityocampa Schiff. (pine processionary caterpillar) and Viscum album L. ssp. austriacum Wiesb. (mistletoe). In: J. Gómez-Zotano, J. Arias-García, J.A. Olmedo-Cobo, J.L. Serrano-Montes [eds.]. Advances in Biogeography. Distribution areas: between bridges and barriers, XI Spanish Congress of Biogeography. Editorial Universidad de Granada-Tundra Ediciones, Granada, 373-381 pp. (in Spanish)

Olmedo-Cobo, J. A., Cunill-Artigas, R., MartínezIbarra, E., Gómez-Zotano, J. 2017. Paleoecología de Abies sp. en Sierra Bermeja (sur de la península ibérica) durante el Holoceno medio a partir del análisis pedoantracológico. Bosque, 38-2, 259-270. (in Spanish with English summary)

Pazouki, L., Salehi, P., Fields, P. D., Martins, K., Suhhorutšenko, M., Viinalass, H., Niinemets, Ü. 2015. Large within-population genetic diversity of the widespread conifer Pinus sylvestris at its soil fertility limit characterized by nuclear and chloroplast microsatellite markers. European Journal of Forest Research 135-1, 161-177.

Pérez-Raya, F., López, J. M., Molero, J.,Valle, F. 1990. Vegetation of Sierra Nevada-Geobotanical Guide of the Field's Outing of the X Phytosociological Conferences. City council of Granada, 122 pp. (in Spanish)
Rivas-Martínez, S., Penas, A., Díaz, T.E. 2004. Bioclimatic \& Biogeographic Maps of Europe. University of León. Avalaible online: http://www.globalbioclimatics.org/form/maps.htm (07.09.2016)

Rivas-Martínez, S. 2008. Bioclimatic Classification of the Earth.Phytosociological Researches Centre, Madrid. Available online: http://www.globalbioclimatics.org/book/bioc/global_bioclimatics-2008_0o.htm (07.09.2016) (in Spanish)

Rivas-Martínez, S., Loidi, J. 1999. Bioclimatology of the Iberian Peninsula. Itinera Geobotanica 13, 41-47.

Rivas-Martínez, S., Díaz, T. E., Penas, A, Fernández, F. [eds.]. 2011. Map Memory of the Spain Potential Vegetation. Itinera Geobotanica 18, 5-800. (in Spanish)

Robledo, J. J., Navascués, M., González, S. C., Gil L. 2009. Genetic introgression in relict populations of Pinus sylvestris L. var. nevadensis of the Sierra Nevada National Park. In: OAPN, Research projects in National Parks: 2005-2008. Ministry of the Environment, Rural and Marine, Madrid, 97-105 pp. (in Spanish with English summary)

Rosúa, J. L., López de Hierro, L., Martín, J. C., Serrano, F. A., Sánchez, A. 2001. Provenances of the Native Vegetal Species of Andalucia used in the restoration of the vegetation cover. Ministry of Environment of the Andalucia Government, Granada, 303 pp. (Vol. I), 316 pp. (Vol. II). (in Spanish)

Ruiz de la Torre, J. 2006. Major flora. Autonomous Agency "National Parks"-General Directorate for Biodiversity, Madrid, 1,756 pp. (in Spanish)

Ruiz-Labourdette, D., Nogués-Bravo, D., Sáinz, H., Schmitz, M. F., Pineda, F. D. 2012. Forest composition in Mediterranean mountains is projected to shift along the entire elevational gradient under climate change. Journal of Biogeography 39, 163-176.

Sancho-Reinoso, A. 2013. Land abandonment and the dynamics of agricultural landscapes in Mediterranean mountain environments: the case of Ribagorça (Spanish Pyrenees). Erdkunde 67-4, 289-308.

Lucdeme Project. 1988. Güéjar-Sierra - 1027, 1:100.ooo. Spanish Ministry of Agriculture, Fisheries and Food - Spain Government, Madrid, 110 pp. (in Spanish)

Lucdeme Project. 1988. Baza - 994, 1:100.00o. Spanish Ministry of Agriculture, Fisheries and Food - Spain Government, Madrid, 160 pp. (in Spanish)

Vera, J. A. 2004. Geology of Spain. IGME, Madrid, 884 pp. (in Spanish)

Svenning, J. C., Skov, F. 2007. Ice age legacies in the geographical distribution of tree species richness in Europe. Global Ecology and Biogeography 16, 234245.

Tzedakis, P. C., Lawson, I. T., Frogley, M. R., Hewitt, G. M., Preece, R. C. 2002. Buffered tree population 
changes in a Quaternary refugium: evolutionary implications. Science 297, 2,044-2,047.

Valle, F., Gómez, F. 1988. Vegetation map of the Sierra de Baza. University of Granada, Granada, 237 pp. (in Spanish)

Valle, F., Navarro, F.B., Jiménez, N. [eds.]. 2003. Map of the Vegetation Series of Andalucia. Ministry of Environment of the Andalucia Government, Madrid, 512 pp. (in Spanish)

Vandvik, V. 2017. Mosses as mediators of climate change: implications for tree seedling establish- ment in the tundra. Unpublished PhD thesis, University of Bergen, Bergen, Norway.

Xenakis, G., Duncan, R., Mencuccini, M. 2012. Effects of climate and site characteristics on Scots pine growth. European Journal of Forest Research 131, 427-439.

Zamora, R., Gómez, J. M., Hódar, J. A., Castro, J. García, D. 2001. Effect of browsing by ungulates on sapling growth of Scots pine in a Mediterranean environment: consequences for forest regeneration. Forest Ecology and Management 144, 33-42. 